Military Technical College Kobry El-Kobbah, Cairo, Egypt

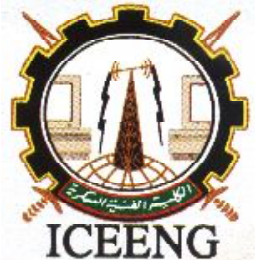

\author{
$9^{\text {th }}$ International Conference \\ on Electrical Engineering \\ ICEENG 2014
}

\title{
Control and Operation Of a Solid Oxide Fuel-Cell Power Plant In an Isolated System
}

\author{
By \\ Hassan H. EL-Tamaly ${ }^{*}$, Hamdy M. Sultan ${ }^{* *}$ and M. Azzam ${ }^{* * *}$
}

\begin{abstract}
:
A dynamic model for a solid oxide fuel cell power plant has been constructed. The concept of a feasible operating area for a solid oxide fuel-cell power plant is introduced by establishing the relationship between the stack terminal voltage, fuel utilization, and stack current. By controlling the input hydrogen fuel in proportion to the stack current, constant utilization control can be accomplished. The effectiveness of the proposed schemes is illustrated through simulation.
\end{abstract}

\section{Keywords:}

Distributed generation, SOFC, Load tracking.

\section{Introduction:}

In Recent Years, environmental and economic considerations have resulted in much increased interest in the application of distributed generation (DG) [1], [2]. DG, such as internal combustion engines, micro turbines, fuel cells, photovoltaic, and wind turbines are typically of $10 \mathrm{~kW}-10 \mathrm{MW}$ in capacity. As these generators are to be incorporated into power systems, their impacts on network reliability and security have come under close scrutiny [3].

FUEL CELLS (FC) are modular, high-efficiency; environmentally friendly energy conversion devices that have become a promising option to replace the conventional fossil fuel- based electric power plants [4]. Among the several kinds of FC, the lowtemperature proton exchange membrane fuel cell (PEMFC) is the most widely used type and has been commercialized for the portable, vehicular, and residential applications [5]. However, due to the lower efficiency and the dependency on pure hydrogen as the fuel input, PEMFC has not been considered for stationary power applications.

$*, * *$ and $* * *$ Faculty of Engineering - Minia University 
Another kind of FC under active research is the high temperature solid oxide fuel cell (SOFC). SOFC presents an attractive option for the DG technology, which generates electricity at or near the load site. The current main challenges to develop this DG technology are to reduce the installation cost, to improve overall efficiency, and to explore the avenues of increasing the durability to more than $40000 \mathrm{~h}$ for stationary power applications [6].

The feasibility of using FC power plant for stationary power supply has been studied by many researchers. In order to ensure that the SOFC would operate successfully in a power system, it is necessary to examine, among other issues, its ability to perform load tracking and its impact on power quality. Central to the studies is the need to have a credible analytical model of the SOFC plant. Thus, building a suitable FC dynamic model is one important aspect in the study of SOFC DG system. An appropriate FC dynamic model should consider the electrochemical- thermodynamic process and electrical performance. A number of models for simulating FC-based power plant have been developed. Lukas et al. provided a nonlinear mathematical model for molten carbonate FC (MCFC) [7]. This model is, however, complex and is difficult to be implemented for power system analysis purposes. Hatziadoniu et al. derived a reducedorder MCFC dynamical model for dynamic stability analysis [8]. Padullés et al. [9] created a simulation model of a solid oxide FC (SOFC) power plant intended for a power system analysis package. Their paper shows that the electrochemical and thermodynamic process could be approximated by first-order transfer functions. Based on the results of [9], Zhu et al. included the SOFC fuel processor in their investigation and used the model to study SOFC load tracking ability [10].

\section{Solid Oxide Fuel Cell Model}

\section{A. Fuel Cell Stack Dynamic Model}

The stack model will be based on the following assumptions.

- The gases are ideal.

- The stack is fed with hydrogen and air. If natural gas instead of hydrogen is used as fuel, the dynamics of the fuel processor must be included in the model, upstream of the hydrogen inlet, as a first-order transfer function [11].

- The temperature is stable at all times.

- The only source of losses is ohmic, as the working conditions of interest are not close to the upper and lower extremes of current.

- The Nernst equation can be applied.

\section{B. Characterization of the exhausts of the channels}

In a typical fuel cell, gaseous fuels are fed continuously to the anode (negative electrode) and an oxidant (i.e., oxygen from air) is fed continuously to the cathode (positive electrode); the electrochemical reactions take place at the electrodes to produce 
an electric current. The electrolyte in the SOFC is a solid, nonporous metal oxide, usually $\mathrm{Y}_{2} \mathrm{O}_{3}$-stabilized $\mathrm{ZrO}_{2}$. Typically, the anode is $\mathrm{Co}-\mathrm{ZrO}_{2}$ or Ni-ZrO $\mathrm{Zr}_{2}$ cermet, and the cathode is Sr-doped $\mathrm{LaMnO}_{3}$ [12]. The basic reactions at the two electrodes of a SOFC can be described as : At the anode of an acid electrolyte fuel cell, the hydrogen gas ionizes, releasing electrons and creating $\mathrm{H}^{+}$ions (or protons).

$$
2 \mathrm{H}_{2} \rightarrow 4 \mathrm{H}^{+}+4 \mathrm{e}^{-}
$$

This reaction releases energy. At the cathode, oxygen reacts with electrons taken from the electrode, and $\mathrm{H}^{+}$ions from the electrolyte, to form water.

$$
\mathrm{O}_{2}+4 \mathrm{e}^{-}+4 \mathrm{H}^{+} \rightarrow 2 \mathrm{H}_{2} \mathrm{O}
$$

According to [9], an orifice that can be considered choked, when fed with a mixture of gases of average molar mass $M(\mathrm{~kg} / \mathrm{kmol})$ and similar specific heat ratios, at a constant temperature, meets the following characteristic:

$$
\frac{\mathrm{W}}{\mathrm{p}_{\mathrm{u}}}=\mathrm{K} \sqrt{\mathrm{M}}
$$

Where $\mathrm{W}$ is the mass flow $(\mathrm{kg} / \mathrm{sec})$; $\mathrm{K}$ is the valve constant, mainly depending on the area of the orifice; $p_{u}$ is the pressure upstream (inside the channel) [atm]. For the particular case of the anode, the concept of fuel utilization $U_{\mathrm{f}}$ can be introduced, as the ratio between the fuel flow that reacts and the fuel flow injected to the stack. $U_{\mathrm{f}}$ is also a way to express the water molar fraction at the exhaust. According to this definition equations (1) and (2) can be written as:

$$
\frac{\mathrm{W}_{\mathrm{an}}}{\mathrm{p}_{\mathrm{an}}}=\mathrm{K}_{\mathrm{an}} \sqrt{\left(1-\mathrm{U}_{\mathrm{f}}\right) \mathrm{M}_{\mathrm{H}_{2}}+\mathrm{U}_{\mathrm{f}} \mathrm{M}_{\mathrm{H}_{2} \mathrm{O}}}
$$

Where, $\mathrm{W}_{\mathrm{an}}$ is the mass flow through the anode valve $[\mathrm{kg} / \mathrm{sec}] ; \mathrm{K}_{\mathrm{an}}$ is the anode valve constant; $\mathrm{M}_{\mathrm{H} 2}, \mathrm{M}_{\mathrm{H} 20}$ are the molecular masses of hydrogen and water, respectively $[\mathrm{kg} / \mathrm{kmol}] ; \mathrm{p}_{\mathrm{an}}$ is the pressure inside the anode channel [atm]. If it could be considered that the molar flow of any gas through the valve is proportional to its partial pressure inside the channel, according to the expressions:

$$
\begin{aligned}
& \frac{\mathrm{q}_{\mathrm{H}_{2}}}{\mathrm{p}_{\mathrm{H}_{2}}}=\frac{\mathrm{K}_{\mathrm{an}}}{\sqrt{\mathrm{M}_{\mathrm{H}_{2}}}}=\mathrm{K}_{\mathrm{H}_{2}} \\
& \frac{\mathrm{q}_{\mathrm{H}_{2} \mathrm{O}}}{\mathrm{p}_{\mathrm{H}_{2} \mathrm{O}}}=\frac{\mathrm{K}_{\mathrm{an}}}{\sqrt{\mathrm{M}_{\mathrm{H}_{2} \mathrm{O}}}}=\mathrm{K}_{\mathrm{H}_{2} \mathrm{O}}
\end{aligned}
$$

Where, $\mathrm{q}_{\mathrm{H} 2}, \mathrm{q}_{\mathrm{H} 2 \mathrm{O}}$ are the molar flows of hydrogen and water, respectively, through the anode valve $[\mathrm{kmol} / \mathrm{sec}] ; \mathrm{p}_{\mathrm{H} 2}, \mathrm{p}_{\mathrm{H} 2 \mathrm{O}}$ are the partial pressures of hydrogen and water, respectively [atm]; $\mathrm{K}_{\mathrm{H} 2}, \mathrm{~K}_{\mathrm{H} 2 \mathrm{O}}$ are the valve molar constants for hydrogen and water, respectively $[\mathrm{kmol} /(\mathrm{sec} . \mathrm{atm})]$. 


\section{Calculation of the partial pressures}

Every individual gas will be considered separately, and the perfect gas equation will be applied to it. Hydrogen will be considered as an example.

$$
\mathrm{p}_{\mathrm{H}_{2}} v_{\mathrm{an}}=\mathrm{n}_{\mathrm{H}_{2}} \mathrm{RT}
$$

Where, $v_{\mathrm{an}}$ is the volume of the anode [9]; $\mathrm{n}_{\mathrm{H} 2}$ is the number of hydrogen moles in the anode channel; $\mathrm{R}$ is the universal gas constant $[\mathrm{atm} /(\mathrm{kmol} . \mathrm{K})]$; $\mathrm{T}$ is the absolute temperature $[\mathrm{K}]$. It is possible to isolate the pressure and to take the time derivative of the previous expression, obtaining:

$$
\frac{\mathrm{d}}{\mathrm{dt}} \mathrm{p}_{\mathrm{H}_{2}}=\frac{\mathrm{RT}}{v_{\mathrm{an}}} \mathrm{q}_{\mathrm{H}_{2}}
$$

Where, $\mathrm{q}_{\mathrm{H} 2}$ is the time derivative of $\mathrm{n}_{\mathrm{H} 2}$, and represents the hydrogen molar flow $[\mathrm{kmol} / \mathrm{sec}]$. There are three relevant contributions to the hydrogen molar flow: the input flow, the flow that takes part in the reaction and the output flow, thus:

$$
\frac{\mathrm{d}}{\mathrm{dt}} \mathrm{p}_{\mathrm{H}_{2}}=\frac{\mathrm{RT}}{v_{\mathrm{an}}}\left(\mathrm{q}_{\mathrm{H}_{2}}^{\text {in }}-\mathrm{q}_{\mathrm{H}_{2}}^{\text {out }}-\mathrm{q}_{\mathrm{H}_{2}}^{\mathrm{r}}\right)
$$

Where, $\mathrm{q}_{\mathrm{H} 2}{ }^{\text {in }}$ is the input flow [kmol/sec]; $\mathrm{q}_{\mathrm{H} 2}{ }^{\text {out }}$ is the output flow $[\mathrm{kmol} / \mathrm{sec}] ; \mathrm{q}_{\mathrm{H} 2}{ }^{\mathrm{r}}$ is the hydrogen flow that reacts $[\mathrm{kmol} / \mathrm{sec}]$. Fuel utilization is the ratio between the fuel flow that reacts and the input fuel flow. Here, we have,

$$
\mathrm{U}_{\mathrm{f}}=\frac{\mathrm{q}_{\mathrm{H}_{2}}^{\mathrm{r}}}{\mathrm{q}_{\mathrm{H}_{2}}^{\mathrm{in}}}
$$

Typically, 80-90\% fuel utilization is used, according to the basic electrochemical relationships, the molar flow of hydrogen that reacts can be calculated as [47]:

$$
\mathrm{q}_{\mathrm{H}_{2}}^{\mathrm{r}}=\frac{\mathrm{NoI}_{\mathrm{fc}}}{2 \mathrm{~F}}=2 \mathrm{~K}_{\mathrm{r}} \mathrm{I}_{\mathrm{fc}}
$$

Where, No is the number of cells associated in series in the stack; $\mathrm{F}$ is the Faraday's constant $[\mathrm{C} / \mathrm{kmol}] ; \mathrm{I}_{\mathrm{fc}}$ is the stack current $[\mathrm{A}] ; \mathrm{K}_{\mathrm{r}}$ is a constant defined for modeling purposes which has a value of $\left(\mathrm{N}_{0} / 4 \mathrm{~F}\right)$ [kmol/ (sec.A)]. Returning to the calculation of the hydrogen partial pressure, it is possible to write:

$$
\frac{\mathrm{d}}{\mathrm{dt}} \mathrm{p}_{\mathrm{H}_{2}}=\frac{\mathrm{RT}}{v_{\mathrm{an}}}\left(\mathrm{q}_{\mathrm{H}_{2}}^{\text {in }}-\mathrm{q}_{\mathrm{H}_{2}}^{\text {out }}-2 \mathrm{~K}_{\mathrm{r}} \mathrm{I}_{\mathrm{fc}}\right)
$$

Replacing the output flow by (5), taking the Laplace transform of both sides and isolating the hydrogen partial pressure, yields the following expression: 


$$
\mathrm{p}_{\mathrm{H}_{2}}=\frac{1 / \mathrm{K}_{\mathrm{H}_{2}}}{1+\tau_{\mathrm{H}_{2}} \mathrm{~s}}\left(\mathrm{q}_{\mathrm{H}_{2}}^{\text {in }}-2 \mathrm{~K}_{\mathrm{r}} \mathrm{I}_{\mathrm{fc}}\right)
$$

where, $\tau_{\mathrm{H} 2}$ expressed in seconds, is the value of hydrogen flow response time. A similar operation can be made for all the reactants and products as below

$$
\begin{gathered}
\mathrm{p}_{\mathrm{O}_{2}}=\frac{1 / \mathrm{K}_{\mathrm{O}_{2}}}{1+\tau_{\mathrm{O}_{2}} \mathrm{~s}}\left(\mathrm{q}_{\mathrm{O}_{2}}^{\text {in }}-2 \mathrm{~K}_{\mathrm{r}} \mathrm{I}_{\mathrm{fc}}\right) \\
\mathrm{p}_{\mathrm{H}_{2} \mathrm{O}}=\frac{1 / \mathrm{K}_{\mathrm{H}_{2} \mathrm{O}}}{1+\tau_{\mathrm{H}_{2} \mathrm{O}} \mathrm{S}} 2 \mathrm{~K}_{\mathrm{r}} \mathrm{I}_{\mathrm{fc}}
\end{gathered}
$$

In order to prevent damage to the electrolyte, the fuel cell pressure difference between the hydrogen and oxygen passing through the anode and cathode gas compartments should be below $4 \mathrm{kPa}$ under normal operation and $8 \mathrm{kPa}$ under transient conditions [9]. The overall fuel cell reaction is given in (1) and (2), so, the stoichiometric ratio of hydrogen to oxygen is 2 to 1 . Oxygen excess is always taken in to let hydrogen react with oxygen more completely. Simulation in our fuel cell system shows that $\mathrm{r}_{\mathrm{H}-\mathrm{O}}$ should be kept around 1.145 in order to keep the fuel cell pressure difference below $4 \mathrm{kPa}$ under normal operation. So the input oxygen flow is controlled to keep $\mathrm{r}_{\mathrm{H}-\mathrm{O}}$ at 1.145 by speed control of the air compressor.

The chemical response in the fuel processor is usually slow as it is associated with the time to change the chemical reaction parameters after a change in the flow of reactants. This dynamic response function is modeled as a first-order transfer function with a 5-sec time constant.

The electrical response time in the fuel cells is generally fast and mainly associated with the speed at which the chemical reaction is capable of restoring the charge that has been drained by the load. This dynamic response function is also modeled as a first-order transfer function but with a 0.8 -sec time constant.

\section{Calculation of the stack voltage}

Applying Nernst's equation and Ohm's law (to consider ohmic losses), the stack output voltage is represented by the following expression:

$$
\mathrm{V}_{\mathrm{fc}}=\mathrm{No}\left(\mathrm{E}_{\mathrm{o}}+\frac{\mathrm{RT}}{2 \mathrm{~F}}\left[\ln \frac{\mathrm{p}_{\mathrm{H}_{2}} \mathrm{p}_{\mathrm{O}_{2}}^{0.5}}{\mathrm{p}_{\mathrm{H}_{2} \mathrm{O}}}\right]\right)-\mathrm{rI}_{\mathrm{fc}}
$$

Where $\mathrm{E}_{\mathrm{o}}$ is the voltage associated with the reaction free energy [V]; $R$ is the same gas constant as previous, but care should be taken with the system unit $[\mathrm{J} /(\mathrm{kmol} \mathrm{K})] ; \mathrm{r}$ describes the ohmic losses of the stack [ ]. 


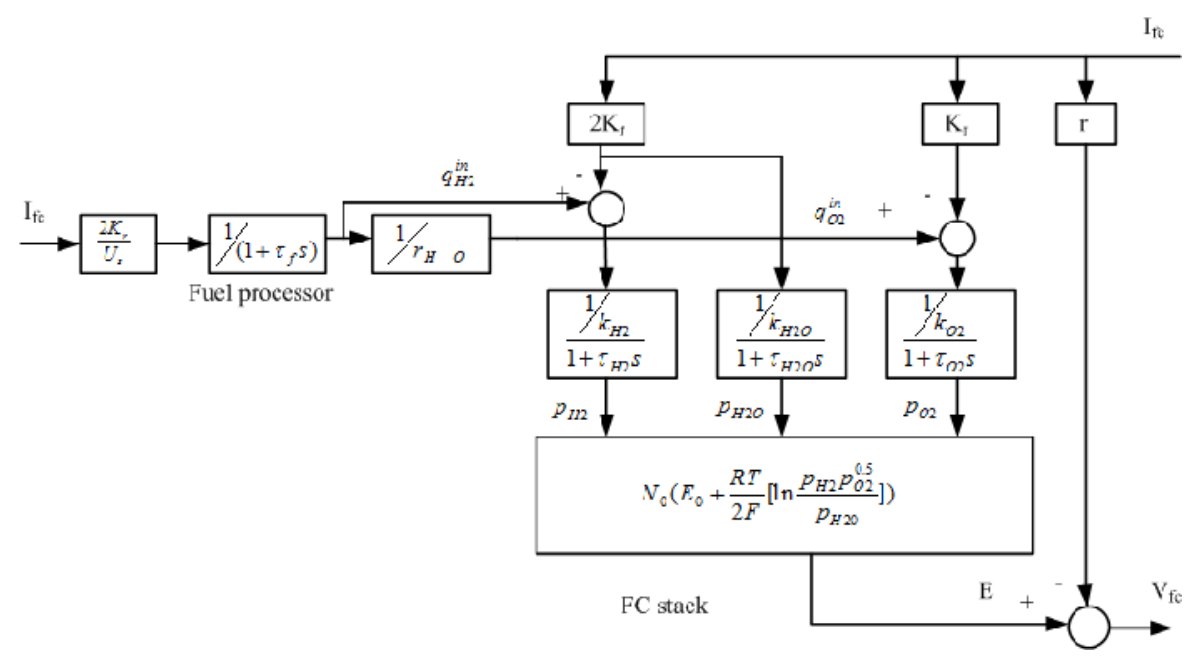

Figure (1): SOFC dynamic model

It can be seen from this figure that the hydrogen and oxygen molar flows with the ratio $\mathrm{r}_{\mathrm{H}-\mathrm{O}}$ are sent to the FC stack where the reactions described by (1) and (2) occur. The partial pressures of the three reactants are generated as the outputs of three first-order transfer functions where $\mathrm{K}_{\mathrm{H} 2}, \mathrm{~K}_{\mathrm{O} 2}$, and $\mathrm{K}_{\mathrm{H} 2 \mathrm{O}}$ are the valve molar constants and $\tau_{\mathrm{H} 2}, \tau_{\mathrm{O} 2}$, and $\tau_{\mathrm{H} 2 \mathrm{O}}$ are the respective temperature-dependent time constants for hydrogen, oxygen, and water, respectively. Typical values of the time-constants are of the order of 3 to 80 second. The production of internal EMF by number of cells in series (No) is represented by the block with the Nernst equation given in (16).

Furthermore, there are three types of losses in the generated EMF, namely, the ohmic loss due to the resistance to the flow of ions and electrons, the activation loss due to sluggish electrode kinetics, and the concentration loss due to the concentration gradient formed at the electrodes [13]. The activation loss is dominant during very low stack currents and the concentration loss is dominant at very high stack currents. The ohmic loss occurs at all levels of currents. Therefore, this study also assumes that $\mathrm{T}$ is constant. This operation with relatively constant temperature also places a lower limit on the FC output power [14].

The stack voltage $\mathrm{V}_{\mathrm{fc}}$ is the actual voltage available at the terminals after considering the losses. The current drawn from the stack $\mathrm{I}_{\mathrm{fc}}$ acts as a feedback to adjust the partial pressures of the reactants according to the reaction rate.

\section{E. Power Conditioning Unit}

Unless the load supplied by the FC plant is of dc type, the power generated by the FC stack invariably has to be converted to ac form by using a power-conditioning unit (PCU). Since the FC terminal voltage varies with the supplied current and the loads are normally designed to operate under constant voltage, the PCU need not only transform 
dc to ac but should also possess voltage controllability. This can be readily achieved by using a pulse width-modulation (PWM). If the FC voltage varies in a large range or the inverter does not possess sufficient voltage controllability, a dc/dc converter is also needed in between the FC terminals and the inverter [15]. In conjunction with the PCU, the primary objective of having the capacitor $\mathrm{C}$ in between the FC stack and the PCU is to filter out the harmonic components generated by the PCU as shown in Figure (2).

Since the PCU keeps the load voltage constant despite changes in FC terminal voltage, a change in real power demand of the ac load appears as a change in dc load current at the FC terminals. Thus, the ac load can be modeled as a variable resistor for the purpose of analyzing the system behavior

\section{Simulation Results and Discussion}

The example in this section is used to illustrate how the control system of an SOFC power plant can be designed to track the variations of load. The example is made on the data given shown in Table (1). The simulation is performed using MATLAB/SIMULINK. At initial condition the FC is operating at its rated operation point. In the following illustration, the load resistance has the following variation. The resistive load is adjusted for $25 \mathrm{KW}$ and still constant until the simulation time reaches five seconds, then the load is resistive load is increased to $40 \mathrm{KW}$. The load voltage is $575 \mathrm{Vrms}$. The controller is designed to adjust constant load voltage under load change. A boost converter is used and controlled to give average voltage of $850 \mathrm{~V}$ under FC voltage change.

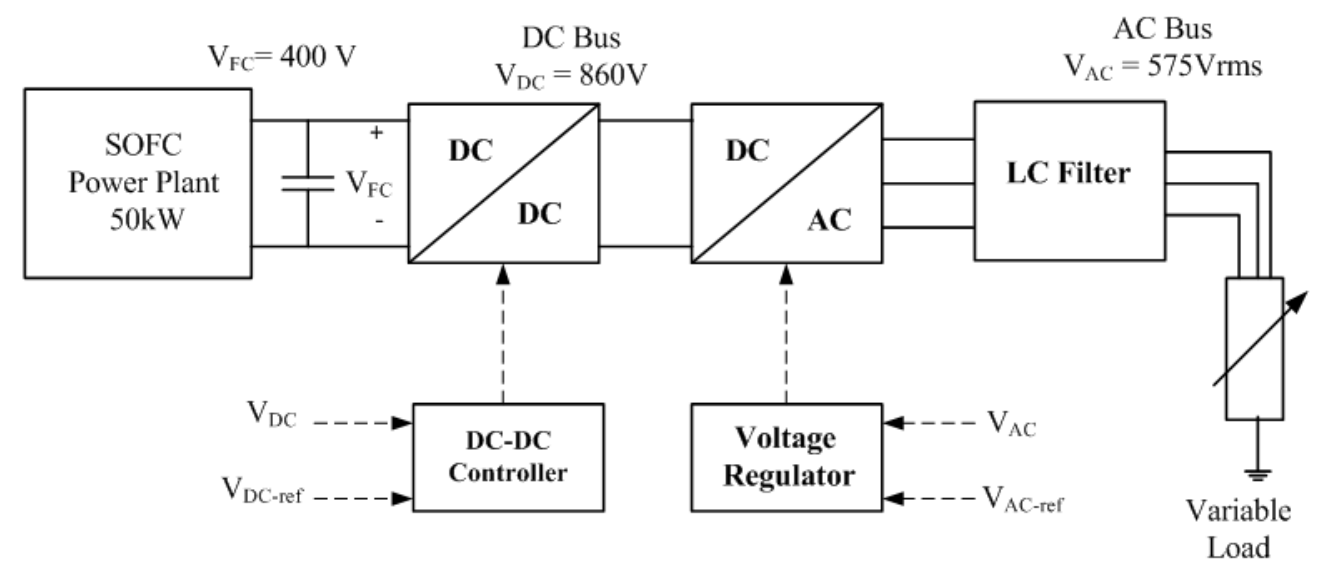

Figure (2): Schematic diagram of the modeled SOFC isolated system.

From simulation results, Figure (4) shows the change of the fuel cell current with time when the load power changed from $25 \mathrm{KW}$ to $40 \mathrm{KW}$ after five second from simulation. Figure (3) shows variation of the stack voltage with time and shows that with increase in fuel cell current the output voltage will decrease. 


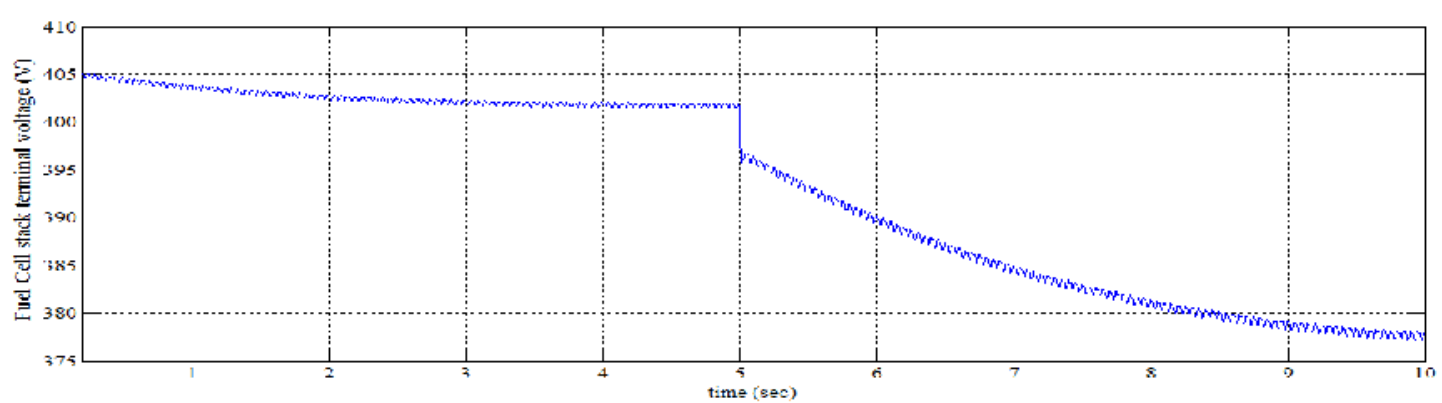

Figure (3): Fuel cell stack voltage variation with time.

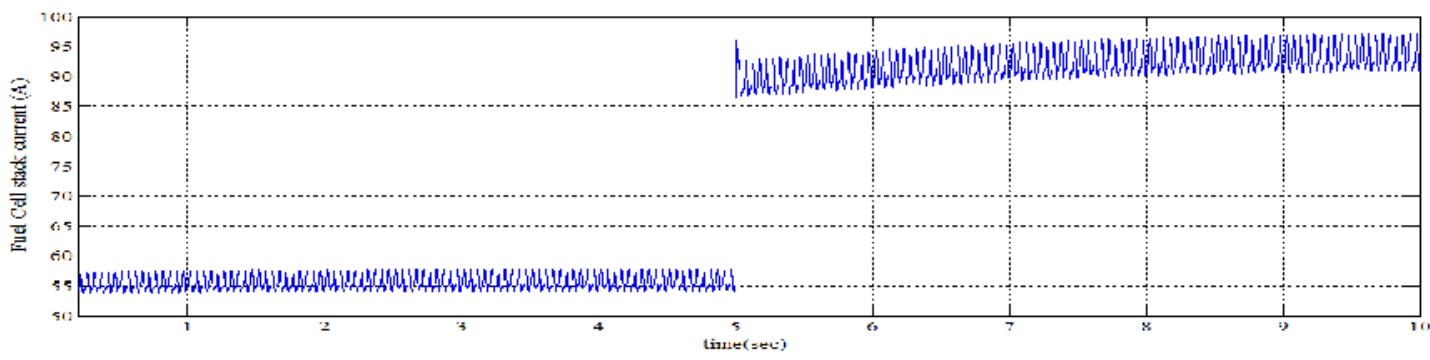

Figure (4): Fuel cell current variation with time.

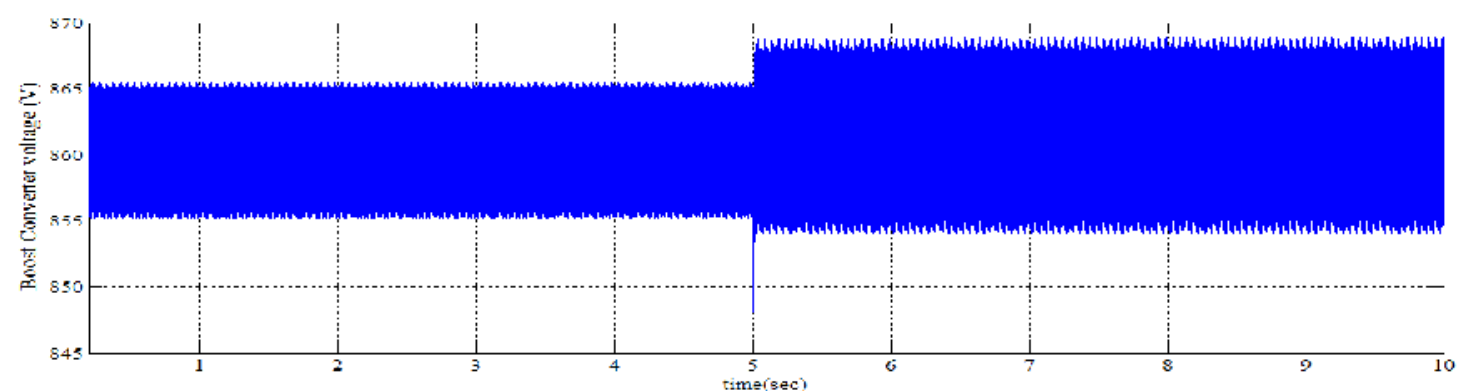

Figure (5): Boost Converter voltage variation with time.

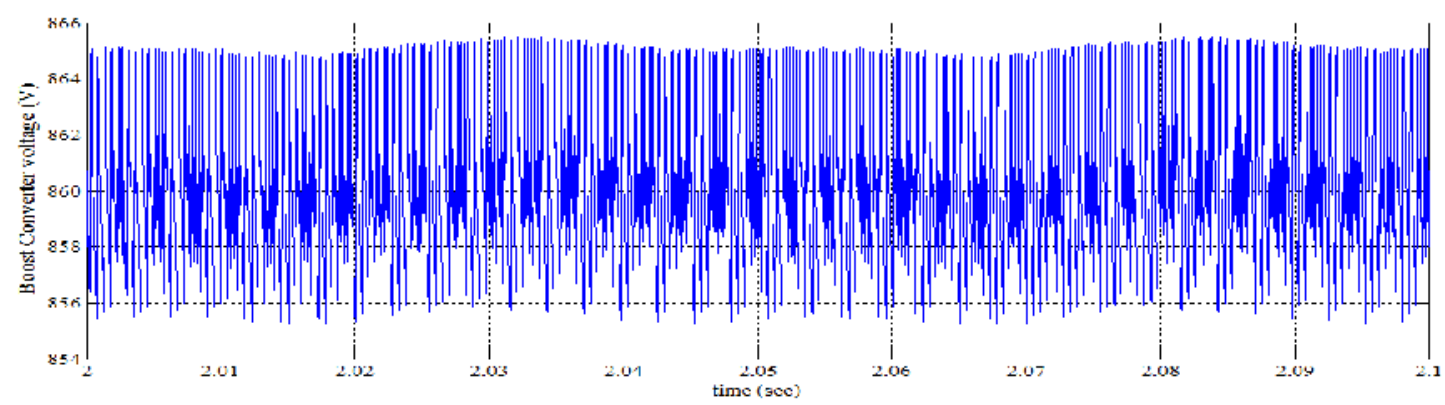

Figure (6): Boost Converter voltage variation with time (zoomed version). 


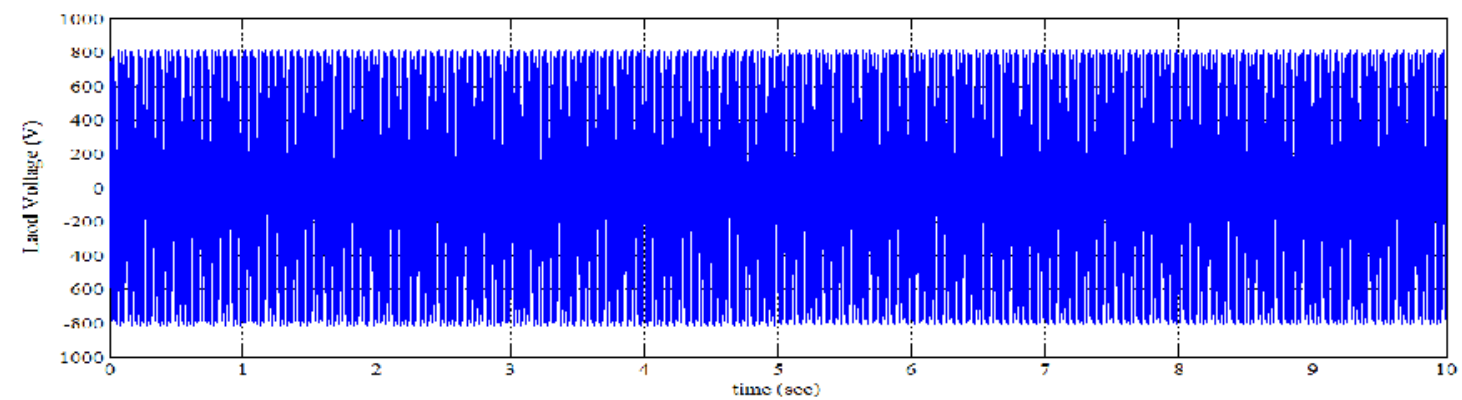

Figure (7): Load voltage variation with time.

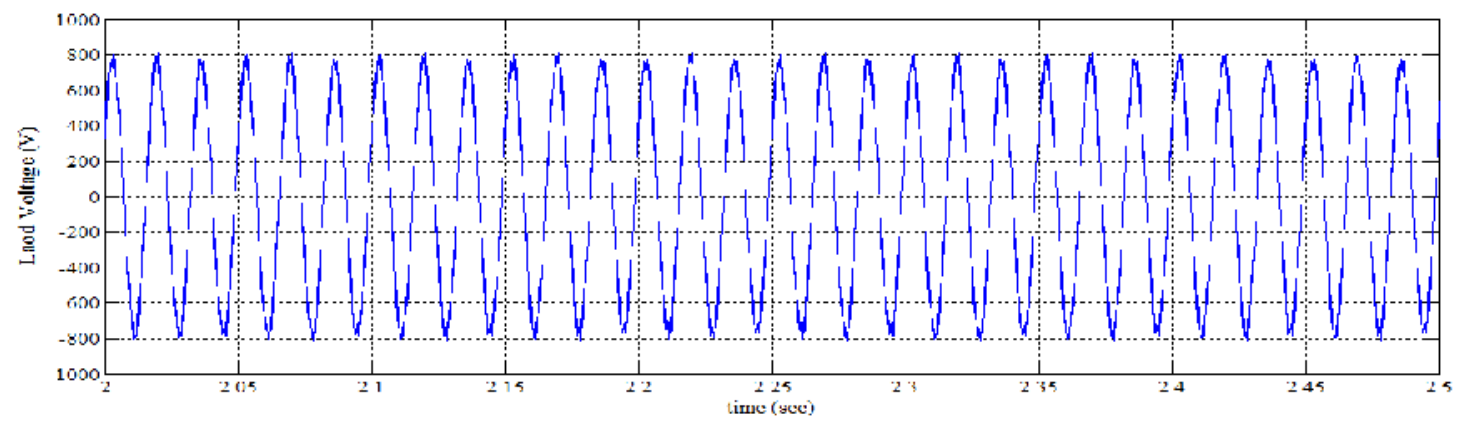

Figure (8): Load voltage variation with time (zoomed version).

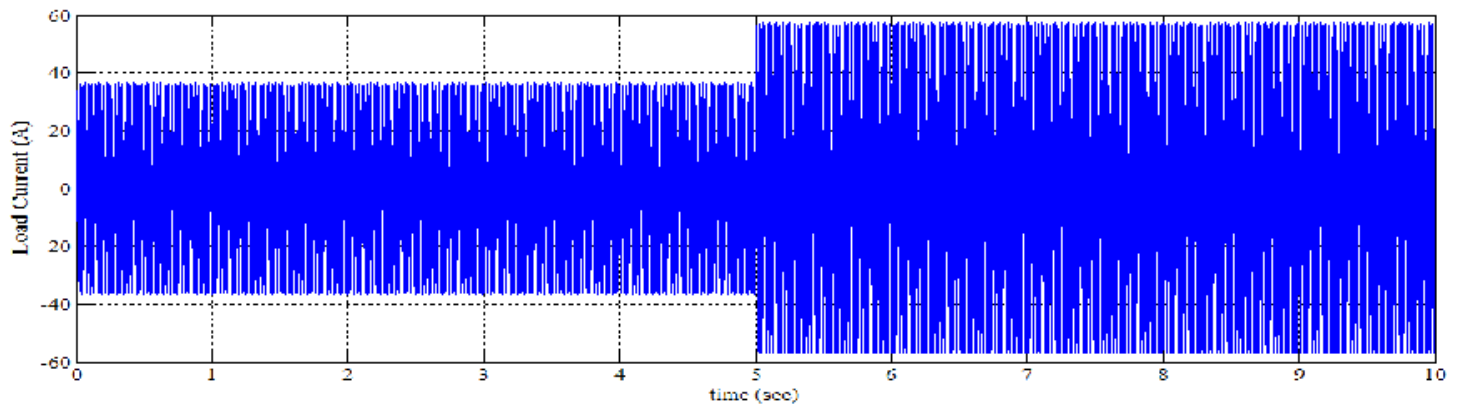

Figure (9): Load current variation with time.

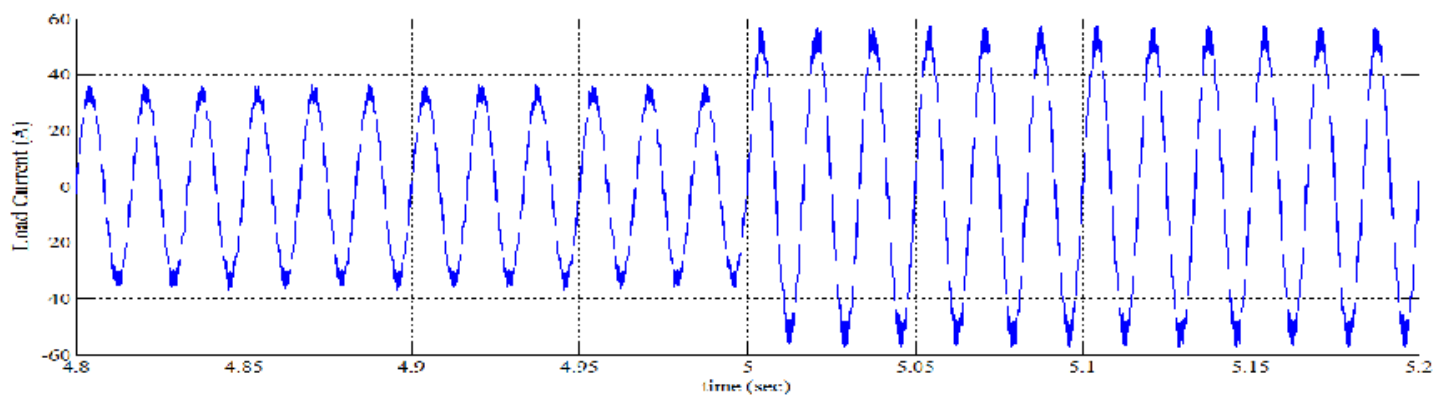

Figure (10): Load current variation with time (zoomed version). 


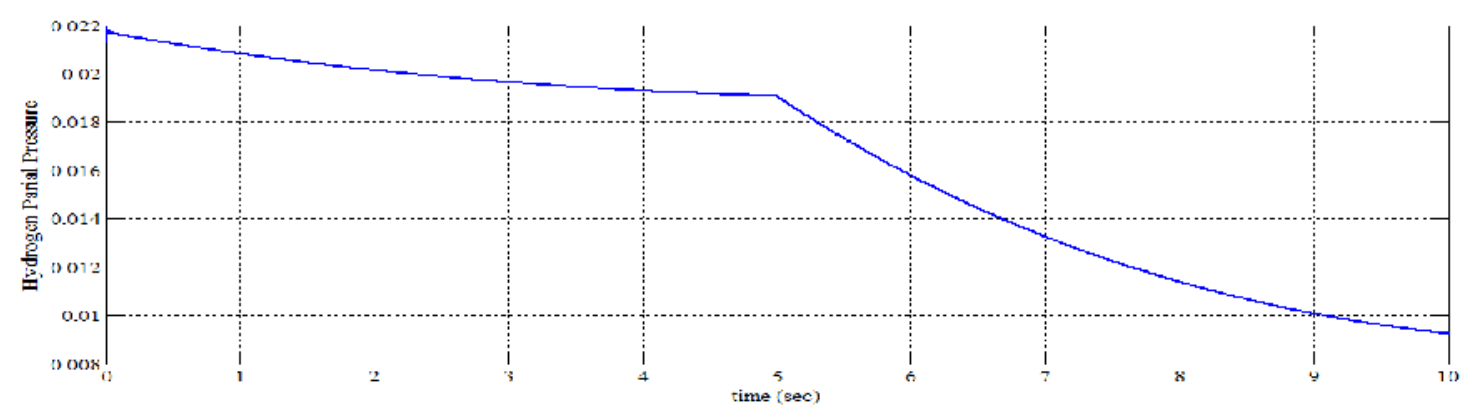

Figure (11): Hydrogen partial pressure variation with time.

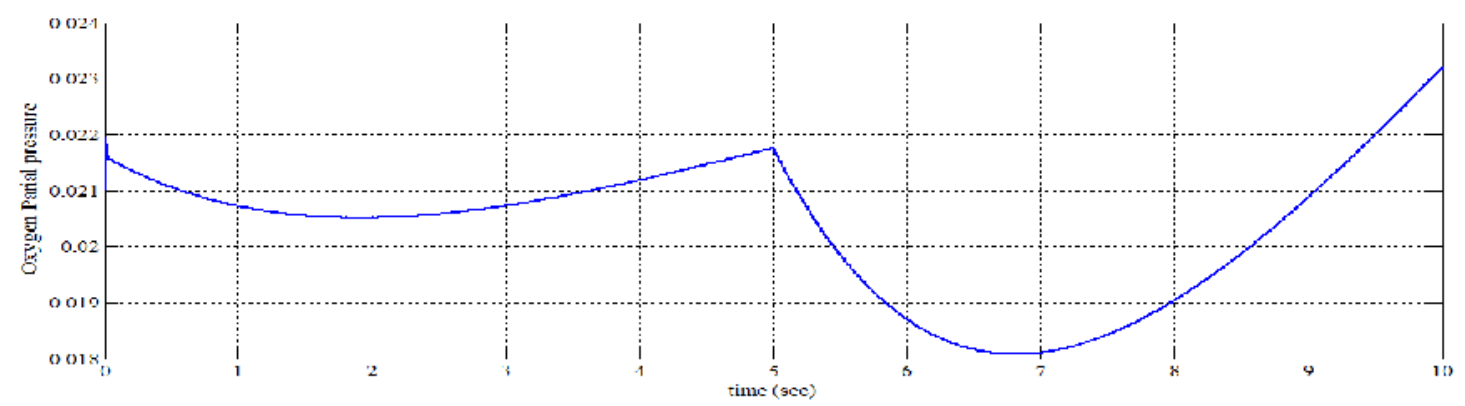

Figure (12): Oxygen partial pressure variation with time.

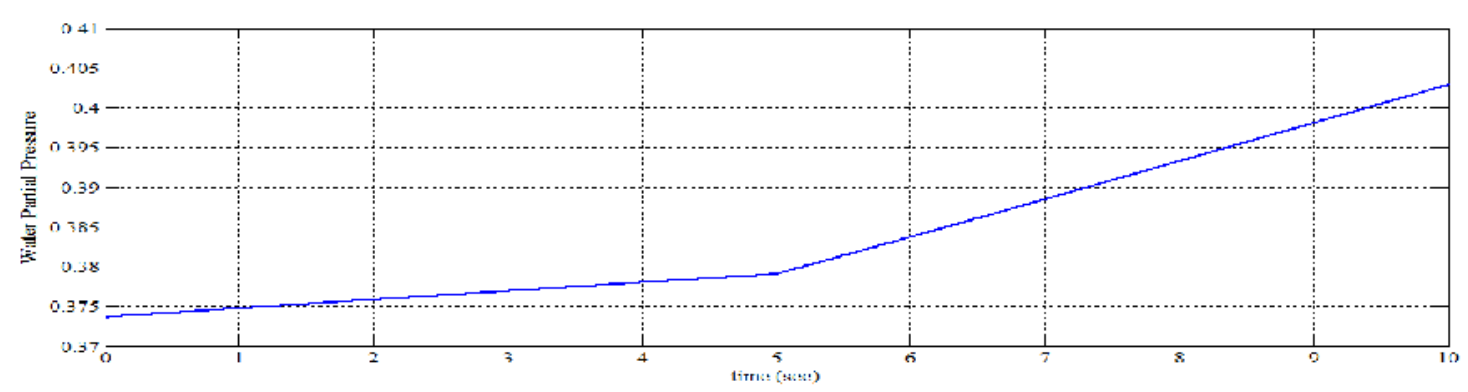

Figure (13): Water partial pressure variation with time.

A boost converter is used to raise the output stack voltage and the reference value of the converter output voltage is set to $860 \mathrm{~V}$. Figure (5) shows the boost converter output voltage and Figure (6) shows a zoomed version of the output voltage and it is shown that the voltage has an average value of $860 \mathrm{~V}$. Load voltage is shown in Figure (7) and a zoomed version of load voltage is shown in Figure (8), which shows that the line to line load voltage approximately equal to $\left(575^{*} \operatorname{sqrt}(2)\right)$. Figure (9) shows the load current and Figure (10) shows a zoomed version which shows that the load current changes as the load power at constant voltage and power factor. Figure (11) and Figure (12) show Hydrogen and Oxygen partial pressure variation with time respectively. As current drawn from fuel cell increases Hydrogen and Oxygen partial pressure will decrease as more Hydrogen and Oxygen will consumed in the chemical reaction, when the current drawn tends to be constant the partial pressure will increase. The opposite action will appear in Water partial pressure variation as shown in Figure (13). 


\section{Conclusion}

A simplified SOFC dynamic model is derived and it is used to study the FC loadtracking capability in an isolated power system. The concept of FOA is introduced in which it becomes a simple tool to assess the possible operating regime of the FC. Power conditioning unit control system keeps constant load voltage under load power variation.

\section{References}

[1] IEEE Standard (Draft) for Distributed Resources Interconnected with Electric Power Systems, Jan. 2002. IEEE P1547.

[2] N. Hatziargyriou et al., "Modeling New Forms of Generation and Storage", CIGRE Tech. Brochure, Nov. 2000TF 38.01.10.

[3] W. H. Lee, "Distributed Power Generation: Planning and Evaluation", Upper Saddle River, NJ: Prentice-Hall, 1998.

[4] M. W. Ellis, M. R. Von Spakovsky, and D. J. Nelson, "Fuel cell systems :Efficient, flexible energy conversion for the 21 st century," Proc. IEEE, Vol. 89, No. 12, pp. 1808-1818, Dec. 2001.

[5] H. Oman, "Electric car progress," IEEE Aerosp. Electron. Syst. Mag., Vol. 17, No. 6, pp. 30-35, Jun. 2002.

[6] R. Kyoungsoo and S. Rahman, "Two-loop controller for maximizing performance of a grid-connected photovoltaic-fuel cell hybrid power plant," IEEE Trans. Energy Convers., Vol. 13, No. 3, pp. 276-281, Sep. 1998.

[7] M. D. Lukas, K. Y. Lee, and H. Ghezel-Ayagh, "Development of a stack simulation model for control study on direct reforming molten carbonate fuel cell power plant," IEEE Trans. Energy Convers., vol. 14, no. 4, pp. 1651-1657, Dec. 1999.

[8] C. J. Hatziadoniu, A. A. Lobo, and F. Pourboghrat, "A simplified dynamic model of grid-connected fuel cell generators," IEEE Trans. Power Del., vol. 17, no. 2, pp. 467473, Apr. 2002.

[9] J. Padullés, G.W. Ault, and J. R. McDonald, "An integrated SOFC plant dynamic model for power systems simulation," J. Power Sources, Vol. 86, No. 1-2, pp. 495500, Mar. 2000.

[10] Y. Zhu and K. Tomsovic, "Development of models for analyzing the loadfollowing performance of micro-turbines and fuel cells," J. Electric Power Syst., Res., Vol. 62, No. 1, pp. 1-11.

[11] T.G. Kreutz, J.M. Ogden, Proceedings of the 1998 Fuel Cell Seminar, 1998, 663.

[12] "Fuel Cell Handbook, EG \& G Technical Services", Inc. Science Applications International Corporation, Morgantown, West Virginia (2002). 
[13] S. Krumdieck, S. Page, and S. Round, "Solid oxide fuel cell architecture and system design for secure power on an unstable grid," J. Power Sources, Vol. 125, No. 1, pp. 189-198, Jan. 2004.

[14] M. Y. EI-Sharkh et al., "Analysis of active and reactive power control of a standalone PEM fuel cell power plant," IEEE Trans. Power Syst.Vol. 19, No. 4, pp. 2022-2028, Nov. 2004.

[15] N. Mohan, T. M. Undeland, and W. P. Robbins, Power Electronics: Converters, Applications, and Design. New York: Wiley, 1993.

\section{Appendix}

Table (1): Parameters of SOFC Power Plant

$\begin{array}{lll}\text { Symbol } & \text { Representation } & \text { Value } \\ \mathbf{P}_{\text {rated }} & \text { Rated power } & 50 \mathrm{KW} \\ \mathbf{V}_{\mathbf{d c} \text { rated }} & \text { Rated FC terminal voltage } & 450 \mathrm{~V} \\ \mathbf{E}_{\mathbf{0}} & \text { Ideal standard potential } & 1.18 \mathrm{~V} \\ \mathbf{N}_{\mathbf{0}} & \text { Number of series cells in stack } & 450 \\ \mathbf{u}_{\mathbf{s}} & \text { Fuel utilization factor } & 0.85 \\ \mathbf{K}_{\mathbf{H 2}} & \text { Hydrogen valve molar constant } & 8.43 \mathrm{e}-4 \mathrm{Kmol} /(\mathrm{s} . \mathrm{atm}) \\ \mathbf{K}_{\mathbf{H 2 O}} & \text { Water valve molar constant } & 2.81 \mathrm{e}-4 \mathrm{Kmol} /(\mathrm{s} . \mathrm{atm}) \\ \mathbf{K}_{\mathbf{O 2}} & \text { Oxygen valve molar constant } & 2.53 \mathrm{e}-3 \mathrm{Kmol} /(\mathrm{s} . \mathrm{atm}) \\ \boldsymbol{\tau}_{\mathbf{H 2}} & \text { Hydrogen flow response time } & 26.1 \mathrm{~s} \\ \boldsymbol{\tau}_{\mathbf{H 2 O}} & \text { Water flow response time } & 78.3 \mathrm{~s} \\ \boldsymbol{\tau}_{\mathbf{O} 2} & \text { Oxygen flow response time } & 2.91 \mathrm{~s} \\ \boldsymbol{\tau}_{\mathbf{f}} & \text { Fuel processor response time } & 5 \mathrm{~s} \\ \mathbf{r} & \text { Ohmic resistance } & 3.28 \mathrm{e}-4 \mathrm{\prime} \Omega \\ \mathbf{r}_{\mathbf{H}-\mathbf{O}} & \text { Ratio of hydrogen and oxygen } & 1.145\end{array}$




\section{Nomenclatures:}

M Average molar mass of gas, $(\mathrm{kg} / \mathrm{kmol})$.

W Mass flow, $(\mathrm{kg} / \mathrm{sec})$.

$\mathrm{U}_{\mathrm{f}} \quad$ Water molar fraction at the exhaust.

$\mathrm{M}_{\mathrm{H} 2}, \mathrm{M}_{\mathrm{H} 20} \quad$ Molecular masses of hydrogen and water, respectively, $(\mathrm{kg} / \mathrm{kmol})$.

$\mathrm{p}_{\mathrm{an}} \quad$ Pressure inside the anode channel, (atm).

$\mathrm{q}_{\mathrm{H} 2}, \mathrm{q}_{\mathrm{H} 2 \mathrm{O}}$ Molar flows of hydrogen and water, respectively, through the anode valve, (kmol/sec).

$\mathrm{p}_{\mathrm{H} 2}, \mathrm{p}_{\mathrm{H} 2 \mathrm{O}}$ Partial pressures of hydrogen and water, respectively, (atm).

$\mathrm{K}_{\mathrm{H} 2}, \mathrm{~K}_{\mathrm{H} 2 \mathrm{O}} \quad$ Valve molar constants for hydrogen and water, respectively

(kmol/(sec.atm)).

$v_{\text {an }} \quad$ Volume of the anode, $\left(\mathrm{m}^{3}\right)$.

$\mathrm{n}_{\mathrm{H} 2} \quad$ Number of hydrogen moles in the anode channel.

$\mathrm{T} \quad$ Absolute temperature, (Kelvin).

$\mathrm{q}_{\mathrm{H} 2}$ in, $\mathrm{q}_{\mathrm{H} 2}$ out Input and output flow respectively, $(\mathrm{kmol} / \mathrm{sec})$.

No Number of cells associated in series in the stack.

$\mathrm{I}_{\mathrm{fc}} \quad$ Fuel cell current, (A).

$\mathrm{V}_{\mathrm{fc}} \quad$ Fuel Cell Stack terminal voltage (V). 